\title{
Postpartum Ovarian Follicular Dynamics and Estrous Activity in Lactating Dairy Cows
}

\author{
M. Sakaguchi, ${ }^{1}$ Y. Sasamoto, ${ }^{2}$ T. Suzuki, ${ }^{2}$ Y. Takahashi, ${ }^{2}$ and $Y$. Yamada $^{1}$ \\ ${ }^{1}$ Department of Animal and Grassland Sciences, \\ National Agricultural Research Center for Hokkaido Region, \\ National Agricultural and Bio-oriented Research Organization, \\ Sapporo 062-8555, Japan \\ ${ }^{2}$ Graduate School of Veterinary Medicine, \\ Hokkaido University, Sapporo 060-0818, Japan
}

\begin{abstract}
The objectives of this study were to characterize early postpartum follicular dynamics in dairy cows in relation to their estrual activity and subsequent reproductive performance using 50 (26 primiparous and 24 multiparous) lactating Holstein cows. Ovaries and uterine horns of postpartum lactating cows were examined by ultrasonography 3 times weekly and continued until first services occurred after a 45 -d voluntary waiting period. No differences were detected in fertility between primiparous and multiparous cows. In 40 of 50 cows, first postpartum ovulation was observed within 4 follicular waves, and the follicular wave patterns and ovarian cycles in most cows returned to normal as in cattle having normal estrous cycles after the second postpartum ovulation. Cows with the longest intervals from calving to first ovulation produced the most milk and also had prolonged intervals to first estrous activity. Differences in follicular dynamics before first ovulation altered intervals to first estrus, first service, and uterine involution, but these differences did not affect pregnancy rate, number of services, and days open. First postpartum insemination after 3 follicular waves tended to have greater pregnancy rates than those after 2 follicular waves. First inseminations at first estrus could produce greater pregnancy rates than those at subsequent periods of estrus.
\end{abstract}

(Key words: estrous activity, follicular dynamics, postpartum fertility)

Abbreviation key: DF = dominant follicle.

\section{INTRODUCTION}

Acceptable reproductive efficiency requires each cow to calve regularly to maximize economic output of milk

Received September 16, 2003.

Accepted January 30, 2004.

Corresponding author: M. Sakaguchi; e-mail: saka99@affrc.go.jp. production in the face of declining reproductive efficiency over the past 2 decades (Roche et al., 2000; Lucy, 2001). Rapid progress in genetics and management in the dairy industry has resulted in increased milk production per cow. Metabolic demands for more milk negatively impact reproductive function of postpartum cows (Beam and Butler, 1999). Those with the greatest milk production have the highest incidence of infertility, but epidemiological studies indicate that, in addition to milk production, other factors probably contribute to decreasing reproductive efficiency in dairy herds (Lucy, 2001).

In dairy cows, resumption of ovarian activity plays an important role in subsequent fertility (Darwash et al., 1997; Smith and Wallace, 1998). Since ultrasound imaging technique has been applied to the study of bovine follicular dynamics (Pierson and Ginther, 1987; Savio et al., 1988; Sirois and Fortune, 1988), most postpartum follicular development occurs in a wave-like manner in normal cycling cattle (Rajamahendran and Taylor, 1990; Savio et al., 1990a). Recent studies have revealed that postpartum anovulatory anestrus in dairy cows is not due to a lack of follicular development, but rather the failure of a dominant follicle (DF) to ovulate (Roche et al., 2000). The first DF is selected within $10 \mathrm{~d}$ after calving in nearly all dairy cows, independent of subsequent reproductive performance (Savio et al., 1990a; McDougall et al., 1995). First ovulation can be observed within 2 wk after calving in dairy cows (Rajamahendran and Taylor, 1990; Savio et al., 1990a; McDougall et al., 1995).

Although follicular dynamics during the normal estrous cycle have been extensively studied as an adjunct to develop effective estrus-synchronization strategies (Ireland et al., 2000), less information on postpartum follicular dynamics is available (Rajamahendran and Taylor, 1990; Savio et al., 1990b). Moreover, the relationship between early follicular dynamics and subsequent fertility is not clear in modern dairy cows. Recently, it was documented that most cattle exhibit 2 or 3 follicular waves during the normal estrous cycle 
(Ireland et al., 2000). However, one and 4-wave cycles are sometimes observed (Sirois and Fortune, 1988; Savio et al., 1988). More recently, Townson et al. (2002) reported that fertility tended to be greater in lactating cows inseminated after ovulation of the third wave DF compared with those inseminated after ovulation of the second wave DF.

Since Thatcher and Wilcox (1973) reported that occurrence of multiple estrous periods (up to 4) during the first 60 DIM was associated with increased conception rate, early resumption of cyclic ovarian activity and occurrence of luteal concentrations of progesterone have been considered beneficial to fertility. However, it is still controversial whether early resumption of ovarian activity improves the fertility of dairy cows (Villa-Godoy et al., 1988; Lucy et al., 1992; Darwash et al., 1997). A recent study demonstrated that early ovulation, which was assessed by milk progesteronedetermined luteal activity before 21 DIM, was associated with reduced pregnancy rates and a prolonged calving to conception interval in multiparous dairy cows (Smith and Wallace, 1998). Early luteal activity may negatively impact involution of the uterus after calving (Lewis, 1997).

The main objective of our study was to characterize the early postpartum follicular dynamics of lactating dairy cows and how timing of resumption of ovarian function influences subsequent reproductive performance of cows, including expression of estrus and conception rate.

\section{MATERIALS AND METHODS}

\section{Cattle}

Data presented in this study were collected from 50 lactating (26 primiparous and 24 multiparous) Holstein cows that calved between October 1999 and June 2001 at the National Agricultural Research Center for Hokkaido Region (Sapporo, Japan). During the first $10 \mathrm{wk}$ after calving, primiparous cows and multiparous cows were housed in a free-stall barn and a tie-stall barn, respectively; thereafter, all 50 cows were housed in the same free-stall barn. Throughout the experimental period, cows were fed a diet to meet maintenance, growth, and lactation requirements in accordance with the Japanese feeding standard (Agriculture, Forestry and Fisheries Research Council Secretariat, 1999). During summer (May to September), cows were pastured for 3 to $4 \mathrm{~h} / \mathrm{d}$, and the amount of diet was reduced to meet the nutritional requirements during this period. Cows were milked twice daily (0900 and $1900 \mathrm{~h}$ ), and milk yield was recorded daily. Average daily milk yield was calculated for the period consisting of 7 to 70 DIM.

\section{Ultrasound Examinations for Ovary and Uterus}

Ovaries of all cows were scanned 3 times weekly using a real-time linear array ultrasound scanner (SSD-620; ALOKA, Tokyo, Japan) equipped with a 5-MHz rectal probe (UST-580U-5; ALOKA) beginning on $d 6$ to $8 \mathrm{~d}$ postpartum and continuing until cows were first inseminated. Follicles $\geq 5 \mathrm{~mm}$ were measured, and diagrams of their relative positions were drawn on each examination day (Savio et al., 1988), allowing individual follicles to be identified for analysis of the follicular waves. A $\mathrm{DF}$ was defined to be the largest follicle that grew to a diameter of $>10 \mathrm{~mm}$ and was at least $2 \mathrm{~mm}$ larger than other follicles (Sirois and Fortune, 1990). To determine the postpartum interval to each ovulation, ovaries were examined daily by rectal palpation in addition to when regular ultrasound examinations were not scheduled. When the largest follicle exceeded $25 \mathrm{~mm}$ in diameter and persisted for $>10 \mathrm{~d}$ in the absence of a corpus luteum (Garverick, 1997), it was classified as a follicular cyst and was not included in data analyses with other normal follicular waves.

Both uterine horns were scanned 3 times weekly by ultrasonography, and the largest diameters of the stratum vasculare were measured at the base of each horn (approximately $5 \mathrm{~cm}$ anterior to the uterine body). Uterine involution was defined to be complete (days postpartum) when diameters of both horns were $<30 \mathrm{~mm}$, and the difference in diameters between the previous gravid and nongravid horns diminished to within $5 \mathrm{~mm}$.

\section{Estrus Detection and Al}

The cows were observed twice daily for at least 30 min before milking. Those exhibiting standing estrus with the aid of a Kamar heatmount detector (Kamar Inc., Steamboat Springs, CO) or mounting activity accompanied by other symptoms such as vaginal mucous discharge and swelling of the vulva were considered to be in estrus. After a 45-d voluntary waiting period, those exhibiting estrus were inseminated artificially using frozen-thawed semen from bulls in which normal fertility had been confirmed. Conception was confirmed by detection of a fetal heartbeat using ultrasonography at 35 to $40 \mathrm{~d}$ after each AI. Because no severe reproductive dysfunction was diagnosed before first AI, no hormonal treatments were applied to cows during this period. After AI, ovaries were examined daily by palpation per rectum until ovulation was confirmed. When ovulation had not occurred by $24 \mathrm{~h}$ after the end of estrous activity, it was diagnosed as a delayed ovulation. When necessary, use of PGF2 $\alpha$ and GnRH was performed to recover some reproductive dysfunctions such as delayed ovulation, persistent corpus luteum, developing cystic follicles, and uterine endometritis. Cows that did not 
Table 1. Reproductive performance and milk yield of postpartum dairy cows differing in parity.

\begin{tabular}{|c|c|c|c|}
\hline & Primiparous & Multiparous & Total \\
\hline \multicolumn{4}{|c|}{ Mean \pm SEM } \\
\hline First ovulation & $26.7 \pm 3.2$ & $35.5 \pm 3.5$ & $30.9 \pm 2.4$ \\
\hline First detected estrus & $47.8 \pm 3.7^{\mathrm{a}}$ & $63.1 \pm 4.4^{\mathrm{b}}$ & $55.2 \pm 3.0$ \\
\hline First service & $65.7 \pm 2.9^{\mathrm{a}}$ & $77.8 \pm 4.0^{\mathrm{b}}$ & $71.5 \pm 2.6$ \\
\hline Uterine involution & $17.3 \pm 0.9$ & $18.3 \pm 0.8$ & $17.8 \pm 0.6$ \\
\hline \multicolumn{4}{|l|}{ Duration, $\mathrm{d}$} \\
\hline First ovarian cycle ${ }^{1}$ & $15.1 \pm 1.1$ & $19.1 \pm 1.3$ & $17.0 \pm 1.1$ \\
\hline Second ovarian cycle ${ }^{2}$ & $20.7 \pm 0.9^{\mathrm{a}}$ & $23.1 \pm 0.7^{\mathrm{b}}$ & $21.8 \pm 0.6$ \\
\hline \multicolumn{4}{|c|}{ Services per conception, no. } \\
\hline By 100 DIM & $1.39 \pm 0.12$ & $1.40 \pm 0.16$ & $1.39 \pm 0.10$ \\
\hline By 180 DIM & $1.65 \pm 0.17$ & $1.59 \pm 0.17$ & $1.62 \pm 0.12$ \\
\hline Total & $1.96 \pm 0.23$ & $1.67 \pm 0.19$ & $1.82 \pm 0.15$ \\
\hline \multicolumn{4}{|l|}{ Days open } \\
\hline By 100 DIM & $73.1 \pm 4.1$ & $77.5 \pm 3.7$ & $75.1 \pm 2.8$ \\
\hline By 180 DIM & $83.1 \pm 5.4$ & $96.4 \pm 7.3$ & $89.6 \pm 4.6$ \\
\hline Adjusted days open ${ }^{3}$ & $93.6 \pm 7.6$ & $99.0 \pm 7.3$ & $96.2 \pm 5.2$ \\
\hline \multicolumn{4}{|l|}{ Cows, no. } \\
\hline Total & $26(52)$ & $24(48)$ & $50(100)$ \\
\hline Pregnant by 100 DIM & $18(69)$ & $15(63)$ & $33(66)$ \\
\hline Pregnant by 180 DIM & $23(88)$ & $22(92)$ & $45(90)$ \\
\hline \multicolumn{4}{|l|}{ Milk yield, kg } \\
\hline Daily (1 to $10 \mathrm{wk}$ ) & $30.0 \pm 0.8^{\mathrm{a}}$ & $42.0 \pm 1.5^{\mathrm{b}}$ & $35.8 \pm 1.2$ \\
\hline $305 \mathrm{~d}$ & $7932 \pm 214^{a}$ & $10,708 \pm 348^{b}$ & $9265 \pm 281$ \\
\hline
\end{tabular}

${ }^{1}$ From first to second ovulation.

${ }^{2}$ From second to third ovulation.

${ }^{3}$ Cows without a positive pregnancy diagnosis by 180 DIM were assigned a days open value equal to 21 $\mathrm{d}$ after their last unsuccessful service.

${ }^{\mathrm{a}, \mathrm{b}}$ Values within rows with different superscripts differ $(P<0.05)$.

have a positive pregnancy diagnosis within the period of this study (first 180 DIM) were assumed to be conceived $21 \mathrm{~d}$ after their last unsuccessful service (Smith and Wallace, 1998), thereby using this adjusted days open as a measure of final fertility.

\section{Statistical Analyses}

All data were analyzed using the Fit Y by X Platform of statistical software JMP (JMP Statistics and Graphics guide, ver. 4.0; SAS Inst., Inc., Cary, NC). Frequencies of ovulation after various follicular waves $(1,2,3,4$, or $>4$ ) until the third ovulation were compared between primiparous and multiparous cows using a chi-square test or Fisher's exact test. Pregnancy rates also were analyzed by the chi-square test or Fisher's exact test. Means between parity groups (primiparous or multiparous), among follicular wave groups ( 2 or 3 waves) before first service, and among different numbers of estrus periods detected (first or later) before first service were determined by using Student's $t$-test. Other differences among numbers of follicular waves were analyzed by one-way ANOVA, and the differences between each follicular wave group were analyzed by Fisher's least significant difference test as a post-ANOVA test.

\section{RESULTS}

\section{Overall Reproductive Performance and Milk Yield}

Table 1 summarizes means for reproductive performance and milk yield for all 50 cows investigated. Duration of the second ovarian cycle $(P<0.05)$, interval to the first detected estrus $(P<0.05)$, and interval to first service $(P<0.05)$ differed between parity groups. However, no significant differences were detected in other reproductive traits such as the interval to first ovulation, duration of the first ovarian cycle, pregnancy rates, numbers of services, and days open. Both daily and 305 -d milk yields in multiparous cows were greater $(P$ $<0.001$ ) than those in primiparous cows.

\section{Follicular Dynamics During the Early Postpartum Period}

Frequencies of ovulation in primiparous cows after one follicular wave $(58 \%$ at first ovulation and $50 \%$ at second ovulation) were greater than those in multiparous cows (33\% at first ovulation and $35 \%$ at second ovulation). However, no differences were detected in the frequencies of cows having various follicular waves before ovulation between primiparous and multiparous 
Table 2. Intervals and distributions of early postpartum ovarian events after various numbers of follicular waves.

\begin{tabular}{|c|c|c|c|c|}
\hline \multirow[b]{2}{*}{ Item } & \multicolumn{4}{|c|}{ Number of follicular waves before each ovulation } \\
\hline & 1 & 2 & 3 or 4 & $>4^{1}$ \\
\hline & & Mean & SEM & \\
\hline $\begin{array}{l}\text { Days to first ovulation } \\
\text { (parturition to first ovulation) }\end{array}$ & $\begin{array}{l}18.1 \pm 1.0^{\mathrm{a}} \\
(\mathrm{n}=23)\end{array}$ & $\begin{array}{l}29.2 \pm 1.5^{\mathrm{b}} \\
(\mathrm{n}=11)\end{array}$ & $\begin{array}{l}38.5 \pm 4.1^{\mathrm{c}} \\
(\mathrm{n}=6)\end{array}$ & $\begin{array}{l}57.6 \pm 4.4^{\mathrm{c}} \\
(\mathrm{n}=10)\end{array}$ \\
\hline $\begin{array}{l}\text { Days to second ovulation } \\
\text { (from first to second ovulation: first cycle) }\end{array}$ & $\begin{array}{l}10.5 \pm 0.5^{\mathrm{a}} \\
(\mathrm{n}=22)\end{array}$ & $\begin{array}{l}20.4 \pm 0.8^{b} \\
(\mathrm{n}=19)\end{array}$ & $\begin{array}{l}20.4 \pm 0.7^{b} \\
(\mathrm{n}=7)\end{array}$ & $\begin{array}{l}45.5 \pm 3.5^{\mathrm{c}} \\
(\mathrm{n}=2)\end{array}$ \\
\hline $\begin{array}{l}\text { Days to third ovulation } \\
\text { (from second to third ovulation: second cycle) }\end{array}$ & $\begin{array}{l}7.5 \pm 1.5^{\mathrm{a}} \\
(\mathrm{n}=2)\end{array}$ & $\begin{array}{l}21.7 \pm 0.4^{b} \\
(\mathrm{n}=34)\end{array}$ & $\begin{array}{l}24.5 \pm 1.0^{\mathrm{c}} \\
(\mathrm{n}=12)\end{array}$ & $\overline{(\mathrm{n}}=0)$ \\
\hline
\end{tabular}

${ }^{1}$ Including cows that developed follicular cysts.

a,b,c,d Values within rows with different superscripts differ $(P<0.05)$.

cows until third ovulation. Frequency of first ovulation after various numbers of follicular waves were $46 \%$ ( 23 of 50) after one wave, $22 \%$ ( 11 of 50 ) after 2 waves, $12 \%$ (6 of 50) after 3 or 4 waves, and 20\% (10 of 50) after $\geq 5$ waves $(n=6)$ or those developing follicular cysts $(n=4)$.

Before second ovulation, $44 \%$ of cows (22 of 50 ) had one wave, $38 \%$ (19 of 50 ) had 2 waves, $14 \%$ (7 of 50 ) had 3 or 4 waves, and $4 \%$ ( 2 of 50 ) had $\geq 5$ waves (each cow developed follicular cysts). One cow that had developed a follicular cyst before first ovulation also developed a second follicular cyst before second ovulation. No cow developed $>4 \mathrm{DF}$ before second ovulation. Before third ovulation, frequency of cows ovulating after one wave was dramatically decreased to $4 \%$ (2 of 48) and that of cows ovulating after 2 and 3 or 4 waves increased to $71 \%$ (34 of 48 ) and $25 \%$ (12 of 48 ), respectively. Although a 4 -wave pattern before third ovulation was observed in one cow, no cow had $>4$ waves before third ovulation. Of the 6 cows that developed follicular cysts before the first and(or) second ovulation, newly developing follicle(s) ovulated spontaneously in the presence of morphologically cystic follicle(s) without any hormonal intervention.

Mean intervals to postpartum ovarian events on the basis of the various numbers of follicular waves before ovulation are summarized in Table 2. Mean days to first ovulation were prolonged $(P<0.05)$ as the number of follicular waves increased before ovulation. The earliest first ovulation was observed in one primiparous cow on d 10 postpartum after having only one follicular wave, and the last first ovulations were detected in one primiparous cow and one multiparous cow on d 79 after having $>4$ waves. Duration of the first ovarian cycle (from first to second ovulation) was less $(P<0.05)$ when second ovulation occurred after one wave; however, those after 2, 3, or 4 waves were within a normal range. For the second ovarian cycle (from second to third ovulation), mean intervals after 3 or 4 waves were greater $(P<0.05)$ than those after only 1 or 2 waves.

\section{Postpartum Reproductive Performance in Relation to Follicular Dynamics Before First Ovulation}

As shown in Table 3, timing of first detected postpartum estrus was earlier $(P<0.05)$ in the cows whose first ovulation occurred after $\leq 2$ follicular waves than in those having $>3$ waves. When first ovulation occurred after $>4$ waves, timing of first service was delayed $(P<$ $0.05)$. In contrast, uterine involution was delayed $(P<$ 0.05 ) in cows with only one follicular wave before the first ovulation. After first service, $\mathrm{PGF}_{2 \alpha}$ was administered to 3 cows, and GnRH given 7 to $10 \mathrm{~d}$ before $\mathrm{PGF}_{2 \alpha}$ was administered to 5 cows for treatment of reproductive dysfunction.

Fertility of cows after 100 or 180 DIM also is summarized in Table 3. After both periods, no differences were detected in conception rates, number of services, or days open. Milk yield in cows having $>4$ follicular waves before first ovulation was greater $(P<0.05)$ than that in cows ovulating after only one wave pattern.

\section{Follicular Dynamics and Estrous Activity Before First Service in Relation to Conception Rate}

One cow conceived at first insemination performed on d 51 postpartum before her third ovulation that followed only one follicular wave during the ovarian cycle that preceded estrus. Otherwise, first services were performed at estrus after 2- or 3-wave cycles for the remaining 49 cows. Two cows were inseminated before second ovulation, 39 cows before third postpartum ovulation, and 8 cows before forth ovulation. Each cow resumed cyclicity without developing follicular cysts before insemination. As shown in Table 4, duration of ovarian cycles before the first service was greater $(P<$ 0.01 ) in cows having 3 -wave cycles than in those having 2 -wave cycles. Pregnancy rate tended $(P=0.07)$ to be greater in cows having 3 -wave cycles than in those having 2 -wave cycles. 
Table 3. Fertility and milk yield in postpartum lactating dairy cows with various numbers of follicular waves before first ovulation.

\begin{tabular}{|c|c|c|c|c|}
\hline \multirow[b]{2}{*}{ Item } & \multicolumn{4}{|c|}{ Number of follicular waves before first ovulation } \\
\hline & 1 & 2 & 3 or 4 & $>4^{1}$ \\
\hline \multirow{2}{*}{ Interval of days postpartum to } & \multicolumn{4}{|c|}{ - Mean \pm SEM } \\
\hline & $42.8 \pm 2.3^{\mathrm{a}}$ & $50.4 \pm 5.1^{\mathrm{a}}$ & $70.5 \pm 4.1^{\mathrm{b}}$ & $79.6 \pm 5.1^{\mathrm{b}}$ \\
\hline First service & $63.1 \pm 2.3^{\mathrm{a}}$ & $68.6 \pm 6.5^{\mathrm{a}}$ & $74.7 \pm 2.2^{\mathrm{ab}}$ & $92.2 \pm 5.4^{\mathrm{b}}$ \\
\hline Uterine diameter involution & $19.9 \pm 0.9^{\mathrm{a}}$ & $15.9 \pm 0.7^{\mathrm{b}}$ & $15.5 \pm 1.7^{\mathrm{b}}$ & $16.3 \pm 1.2^{\mathrm{b}}$ \\
\hline \multicolumn{5}{|l|}{ Services per conception, no. } \\
\hline By 100 DIM & $1.44 \pm 0.13$ & $1.57 \pm 0.20$ & $1.00 \pm 0.00$ & $1.33 \pm 0.33$ \\
\hline By 180 DIM & $1.68 \pm 0.19$ & $1.91 \pm 0.25$ & $1.40 \pm 0.40$ & $1.30 \pm 0.23$ \\
\hline Total & $1.96 \pm 0.23$ & $1.91 \pm 0.25$ & $2.00 \pm 0.68$ & $1.30 \pm 0.21$ \\
\hline \multicolumn{5}{|l|}{ Days open } \\
\hline By 100 DIM & $72.6 \pm 4.7$ & $74.4 \pm 6.7$ & $72.3 \pm 2.3$ & $84.2 \pm 4.1$ \\
\hline By 180 DIM & $79.5 \pm 5.6$ & $97.5 \pm 11.0$ & $90.6 \pm 18.4$ & $99.5 \pm 8.7$ \\
\hline Adjusted days open ${ }^{2}$ & $92.2 \pm 8.2$ & $97.5 \pm 11.0$ & $103.5 \pm 19.8$ & $99.5 \pm 8.7$ \\
\hline \multicolumn{5}{|l|}{ Cows, no. } \\
\hline Total & $23(46)$ & $11(22)$ & $6(12)$ & 10 \\
\hline Pregnant by 100 DIM & $16(70)$ & $7(63)$ & $4(67)$ & $6(60)$ \\
\hline Pregnant by 180 DIM & $19(83)$ & $11(100)$ & $5(83)$ & $10(100)$ \\
\hline \multicolumn{5}{|l|}{ Milk yield, kg } \\
\hline Daily ( 1 to $10 \mathrm{wk}$ ) & $32.7 \pm 1.7^{\mathrm{a}}$ & $36.6 \pm 2.1^{\mathrm{ab}}$ & $36.7 \pm 3.2^{\mathrm{ab}}$ & $41.6 \pm 2.0^{\mathrm{b}}$ \\
\hline $305 \mathrm{~d}$ & $8519 \pm 402^{\mathrm{a}}$ & $9390 \pm 516^{\mathrm{ab}}$ & $9553 \pm 908^{\mathrm{ab}}$ & $10,671 \pm 515^{\mathrm{b}}$ \\
\hline
\end{tabular}

${ }^{1}$ Includes cows that developed follicular cysts.

${ }^{2}$ Cows without a positive pregnancy diagnosis by 180 DIM were assigned a days open value equal to 21 $\mathrm{d}$ after their last unsuccessful service.

${ }^{\mathrm{a}, \mathrm{b}}$ Values within rows with different superscripts differ $(P<0.05)$.

Of the 50 cows, percentages of animals that expressed first detected estrous activity before first, second, third, and fourth ovulation were $10,50,34$, and $6 \%$, respectively. Three cows (6\%) showed estrous activity before each of the first 3 postpartum ovulations. After first estrus was detected before first ovulation, 2 of 5 cows returned to anestrus before second ovulation. After the first estrus was detected before second ovulation, 5 of 25 cows also returned to anestrus before third ovulation. When cows were inseminated at first detected estrus, their conception rate was greater $(P<0.05)$ than that in cows inseminated at the second or third estrus, but days to first service did not differ between the two groups (Table 5).

\section{DISCUSSION}

\section{Overall Reproductive Performance}

Overall reproductive performance demonstrated that delayed timing of first estrus and first insemination in multiparous cows did not influence final fertility when assessed by the number of services per conception and days open in comparison with the final fertility of primiparous cows. Overall, $90 \%$ of the 50 cows studied conceived by 180 DIM. Because days open of cows that conceived was $90 \mathrm{~d}$, it was suggested that modern highproducing dairy cows have the potential to maintain calving intervals averaging $1 \mathrm{yr}$. Thus, the reproductive potential by itself may not be a major cause of the

Table 4. Relationship of fertility to ovarian follicular waves before first postpartum service in lactating cows.

\begin{tabular}{llll}
\hline $\begin{array}{l}\text { Follicular } \\
\text { waves before } \\
\text { first service, no. }\end{array}$ & $\begin{array}{l}\text { Duration of ovarian cycle } \\
\text { before first service, d } \\
(\text { mean } \pm \text { SEM) }\end{array}$ & $\begin{array}{l}\text { Postpartum days } \\
\text { at first service } \\
(\text { mean } \pm \text { SEM) }\end{array}$ & $\begin{array}{l}\text { Proportion of } \\
\text { cows pregnant } \\
(\%)\end{array}$ \\
\hline 2 & $21.0 \pm 0.4^{\mathrm{a}}$ & $70.6 \pm 2.9$ & $16 / 38(42)^{\mathrm{c}}$ \\
3 & $24.1 \pm 1.1^{\mathrm{b}}$ & $76.7 \pm 5.7$ & $8 / 11(73)^{\mathrm{d}}$ \\
Total & $21.7 \pm 0.4$ & $71.9 \pm 2.6$ & $24 / 49(49)$ \\
\hline
\end{tabular}

${ }^{\mathrm{a}, \mathrm{b}}$ Values within columns with different superscripts differ $(P=0.002)$.

${ }^{\mathrm{c}, \mathrm{d}}$ Values within column with different superscripts tended $(P=0.07)$ to differ. 
Table 5. Relationship of fertility to the number of estrus periods detected before first postpartum service in lactating cows.

\begin{tabular}{lll}
\hline $\begin{array}{l}\text { Estrus at } \\
\text { first service }\end{array}$ & $\begin{array}{l}\text { Days at } \\
\text { first service } \\
(\text { mean } \pm \text { SEM) }\end{array}$ & $\begin{array}{l}\text { Proportion of } \\
\text { cows pregnant } \\
(\%)\end{array}$ \\
\hline First & $69.4 \pm 3.1$ & $15 / 22(68)^{\mathrm{a}}$ \\
Second or third & $73.2 \pm 3.9$ & $10 / 28(36)^{\mathrm{b}}$ \\
Total & $71.5 \pm 2.6$ & $25 / 50(50)$ \\
\hline
\end{tabular}

${ }^{\mathrm{a}, \mathrm{b}}$ Values within columns with different superscripts $\operatorname{differ}(P<$ $0.05)$.

continuous decline in reproductive performance of the modern high-yielding cows. This postulation is supported by the results from a large-scale study in New York Holstein cows that indicated conception and insemination might be influenced by factors related to culling and disease history of cows, but that increased milk yield played a minor role (Eicker et al., 1996).

Based on results of a 20-yr selection study, Harrison et al. (1990) speculated that high milk production is antagonistic to the expression of estrous behavior but not to the re-initiation of postpartum ovarian function. Our results are consistent with their first speculation on estrus expression. In contrast, Beam and Butler (1999) reported that greater milk yields often induce negative energy balance in lactating cows, resulting in delayed resumption of ovarian activity. In our study, the latest first ovulation group with $>4$ waves had greater milk production than the earliest first ovulation group after a one-wave pattern. We suggest that high milk yields in cows with $>4$ waves or for those that developed follicular cysts might also be one cause of the delayed occurrence of first ovulation through negative energy balance.

\section{Follicular Dynamics During Early Postpartum Period}

Our results indicate that lactating cows often showed one-wave or $>4$-wave patterns before second ovulation. Our results confirm a previous report (Savio et al., 1990a) in which $74 \%$ of 22 lactating cows ovulated after one follicular wave, $5 \%$ ovulated after 3 waves, and $21 \%$ became cystic. Differences in intervals to first ovulation among cows with $1,2,3,4$, or $>4$ follicular waves indicated that timing of first ovulation depended on the number of follicular waves before ovulation. Further, occurrence of $>4$ waves before the first ovulation delayed that interval by approximately $50 \mathrm{~d}$ compared with cows having only one follicular wave before ovulation.

Second ovulation often occurs after a short luteal phase (Rajamahendran and Taylor, 1990; Savio et al., 1990b; McDougall et al., 1995). That $44 \%$ of second ovulations were observed after only one-wave, short ovarian cycles in our study is consistent with those previous reports. To explain this phenomenon, Mann and Lamming (2000) postulated that, before the first postpartum ovulation, a low concentration of preovulatory estradiol may result in the early generation of a luteolytic mechanism during the subsequent luteal phase because of impaired inhibition of oxytocin receptors that allow early release of $\mathrm{PGF}_{2 \alpha}$. In contrast to the second ovarian cycle, duration of the first cycle with 3 or 4 waves was similar to that having 2 waves. This similarity might indicate that luteal activity during the first ovarian cycle was compromised compared with that during the second cycle. Durations of second postpartum ovarian cycles were similar to those reported in a previous study (Townson et al., 2002). Before second and third ovulation, the ratio of 2 waves to 3 or 4 waves was approximately $3: 1$, and this tendency also was consistent with the latter report (Townson et al., 2002). Thus, it seems that ovarian follicular dynamics and intervals between ovulation in lactating cows is restored to normality after the second postpartum ovulation.

\section{Relationship Between Fertility and Follicular Dynamics Before First Ovulation}

Cows having first ovulation within 2 follicular waves exhibited their first estrus earlier than those having $>3$ waves. Difference in timing of first expressed estrus indicates that prolonged anovulation in modern dairy cows may be attributed to the increased number of follicular waves required to occur before the first ovulation. Delayed first ovulation after $>4$ follicular waves prolonged intervals to first service. However, among cows with $1,2,3,4$, or $>4$ waves, no differences were detected in pregnancy rates and days open. Mean numbers of services per conception by 180 DIM in cows ovulating after $\geq 3$ waves were $<1.4$ and were relatively less than those ovulating after 1 or 2 waves. This trend might explain the small difference in the mean days open among the different wave pattern groups.

Uterine involution and resumption of cyclic ovarian activity play an important role in the subsequent fertility of dairy cows (Lewis, 1997). From parturition until first ovulation, a period when concentrations of progesterone are minimal, the uterus is resistant to infections, and purulent uterine infections seldom develop during this period. After ovulation, when concentrations of progesterone increase, the uterine immune system becomes down-regulated, creating a uterus that is susceptible to infection (Lewis, 1997). It has been suggested that luteal concentrations of progesterone after early first ovulation increase the occurrence of uterine infections (Lewis, 1997) and reduce fertility (Smith and Wallace, 1998) in dairy cows. In the present study, days 
required for uterine involution in cows having one wave were greater than those ovulating after $\geq 2$ waves. Delayed uterine involution might be caused by early exposure of the uterus to progesterone and might explain why no difference was detected in days open among the 4 groups classified by the number of follicular waves before first ovulation.

\section{Numbers of Waves Before Service and Detected Estrus Activity on Fertility}

All cows in our study received their first service after 2 or 3 follicular waves except for one that was inseminated after one wave. Conception rate of cows first inseminated after cycles consisting of 2 follicular waves tended to be lower than that after cycles with 3 follicular waves. Because the ovulatory follicle in cows with 2 waves is more mature than that in cows with 3 waves (Ginther et al., 1989), Townson et al. (2002) hypothesized that fertility would be less in cows with 2 waves. They demonstrated this to be the case after studying 104 lactating dairy cows in which pregnancy rates for 2 -wave cows tended to be less than that of 3 -wave cows. As suggested by Townson et al. (2002), potential differences in the fertility of cows after 2 or 3 waves may provide opportunity for genetic selection to enhance fertility in cattle. Further investigation is warranted because of the relatively small number of cows examined in both studies.

Delayed resumption of cyclic ovarian activity accompanied by more follicular waves before first ovulation delayed onset of first estrous activity, whereas pregnancy rate in cows inseminated at the second or later estrus was almost one-half of that at first estrus. Some cows returned to anestrus after showing their first estrus at first or second ovulation, and cows showing later first estrus often were inseminated at their first detected estrus. Therefore, it is suggested that in modern dairy cows that resume ovarian activity later postpartum, first service at first detected estrus could improve pregnancy rate. Although this result is preliminary, these findings contradict the previous observations in which occurrence of multiple estrus periods during the first $60 \mathrm{~d}$ after calving was associated with increased pregnancy rate (Thatcher and Wilcox, 1973). Although the precise reason for this conflict cannot be determined from our results, we suppose that the great increase in milk yield of dairy cows during the last 3 decades might have induced some undesirable changes in the reproductive physiology of dairy cows.

\section{CONCLUSIONS}

It was demonstrated that $80 \%$ of the first postpartum ovulations in lactating dairy cows occurred after $\leq 4$ follicular waves. Most cows regained a normality of ovarian follicular dynamics after second ovulation. Those with the latest first ovulations after $>4$ follicular waves or after developing follicular cysts produced more milk. Postpartum ovarian dynamics affected timing of the first ovulation and other reproductive traits before the first service but did not have significant effects on the fertility of lactating cows as indicated by the number of services per conception and days open. As preliminary results using the breeding schedule applied in the present study (45-d volunteer waiting period), first services before ovulations after ovarian cycles with 3 follicular waves tended to have greater fertility than those before ovulations after 2 -wave patterns. In normal cows, first services at the first estrus can result in a greater conception rate than that after the second or third estrus.

\section{ACKNOWLEDGMENT}

A part of this study was supported by a Grant-in Aid of Scientific Research (No. 13460136) from the Japan Society for the Promotion of Science.

\section{REFERENCES}

Agriculture, Forestry and Fisheries Research Council Secretariat. 1999. Japanese Feeding Standard for Dairy Cattle. Central Association of Livestock Industry, Tokyo, Japan.

Beam, S. W., and W. R. Butler. 1999. Effects of energy balance on follicular development and first ovulation in postpartum dairy cows. J. Reprod. Fertil. (Suppl.) 54:411-424.

Darwash, A. O., G. E. Lamming, and J. A. Woolliams. 1997. The phenotypic association between the interval to post-partum ovulation and traditional measures of fertility in dairy cattle. Anim. Sci. 65:9-16.

Eicker, S. W., Y. T. Gröhn, and J. A. Hertl. 1996. The association between cumulative milk yield, days open, and days to first breeding in New York Holstein cows. J. Dairy Sci. 79:235-241.

Garverick, H. A. 1997. Ovarian follicular cysts in dairy cows. J. Dairy Sci. 80:995-1004.

Ginther, O. J., L. Knopf, and J. P. Kastelic. 1989. Temporal associations among ovarian events in cattle during oestrous cycles with two and three follicular waves. J. Reprod. Fertil. 87:223-230.

Harrison. R. O., S. P. Ford, J. W. Young, A. J. Conley, and A. E. Freeman. 1990. Increased milk production versus reproductive and energy status of high producing dairy cattle. J. Dairy Sci. 73:2749-2758.

Ireland, J. J., M. Mihm, E. Austin, M. G. Diskin, and J. F. Roche. 2000. Historical perspective of turnover of dominant follicles during the bovine estrous cycle: Key concepts, studies, advancements, and terms. J. Dairy Sci. 83:1648-1658.

Lewis, G. S. 1997. Uterine health and disorders. J. Dairy Sci. 80:984-994.

Lucy, M. C. 2001. Reproductive loss in high-producing dairy cattle: Where will it end? J. Dairy Sci. 84:1277-1293.

Lucy, M. C., C. R. Staples, W. W. Thatcher, P. S. Erickson, R. M. Cleale, J. L. Firkins, J. H. Clark, M. R. Murphy, and B. O. Brodie. 1992. Influence of diet composition, dry matter intake, milk production and fertility in dairy cows. Anim. Prod. 54:323-331.

Mann, G. E., and G. E. Lamming. 2000. The role of sub-optimal preovulatory oestradiol secretion in the aetiology of premature luteolysis during the short oestrous cycle in the cow. Anim. Reprod. Sci. 64:171-180. 
McDougall, S., C. R. Burke, and K. L. MacMillan. 1995. Patterns of follicular development during periods of anovulation in pasturefed dairy cows after calving. Res. Vet. Sci. 58:212-216.

Pierson, R. A., and O. J. Ginther. 1987. Follicular populations during the estrous cycle in heifers I. Influence of day. Anim. Reprod. Sci. 14:165-176.

Rajamahendran, R., and C. Taylor. 1990. Characterization of ovarian activity in postpartum dairy cows using ultrasound imaging and progesterone profiles. Anim. Reprod. Sci. 22:171-180.

Roche, J. F., D. Mackey, and M. D. Diskin. 2000. Reproductive management of postpartum cows. Anim. Reprod. Sci. 60-61:703-712.

Savio, J. D., L. Keenan, M. P. Boland, and J. F. Roche. 1988. Pattern of growth of dominant follicles during the oestrus cycle of heifer. J. Reprod. Fertil. 83:663-671.

Savio, J. D., M. P. Boland, N. Hynes, and J. F. Roche. 1990a. Resumption of follicular activity in the early post-partum period of dairy cows. J. Reprod. Fertil. 88:569-579.

Savio, J. D., M. P. Boland, and J. F. Roche. 1990b. Development of dominant follicles and length of ovarian cycles in post-partum dairy cows. J. Reprod. Fertil. 88:581-591.
Sirois, J., and J. E. Fortune. 1988. Ovarian follicular dynamics during the estrous cycle in heifers monitored by real-time ultrasonography. Biol. Reprod. 39:308-317.

Sirois, J., and J. E. Fortune. 1990. Lengthening the bovine estrous cycle with low levels of exogenous progesterone: A model for studying ovarian follicular dominance. Endocrinology 127:916-925.

Smith, M. C. A., and J. M. Wallace. 1998. Influence of early post partum ovulation on the re-establishment of pregnancy in multiparous and primiparous dairy cattle. Reprod. Fertil. Dev. 10:207-216.

Thatcher, W. W., and C. J. Wilcox. 1973. Postpartum estrus as an indicator of reproductive status of the dairy cow. J. Dairy Sci. 56:608-610.

Townson, D. H., P. C. W. Tsang, W. R. Butler, M. Frajblat, L. C. Griel, Jr., C. J. Johnson, R. A. Milvae, G. M. Niksic, and J. L. Pate. 2002. Relationship of fertility to ovarian follicular waves before breeding in dairy cows. J. Anim. Sci. 80:1053-1058.

Villa-Godoy, A., T. L. Hughes, R. S. Emery, L. T. Chapin, and R. L. Fogwell. 1988. Association between energy balance and luteal function in lactating dairy cows. J. Dairy Sci. 71:1063-1072. 